\title{
Extracts From Leaves of Allamanda blanchetti Inducing Mechanism of Defense to Diseases in Sugarcane
}

\author{
Louise M. S. Oliveira ${ }^{1}$, Clebia M. A. Almeida ${ }^{2}$, Alexandre Gomes da Silva ${ }^{3,4}$, Bruno Oliveira de Veras ${ }^{1}$, \\ Fernanda Granja da Silva Oliveira ${ }^{2}$, Juciara Carneiro Gouveia Tenório ${ }^{1}$, Maria Tereza dos Santos Correia ${ }^{1,2,4}$, \\ Leonardo Sousa Cavalcanti ${ }^{5}$, Rildo S. B. Coelho (In Memoriam) ${ }^{6}$ \& Márcia Vanusa da Silva ${ }^{1,2,4}$ \\ ${ }^{1}$ Programa de Pós-Graduação em Ciências Biológicas, Universidade Federal de Pernambuco, Recife, PE, Brazil \\ ${ }^{2}$ Departamento de Bioquímica, Universidade Federal de Pernambuco, Recife, PE, Brazil \\ ${ }^{3}$ Instituto Nacional do Semiárido, Ministério da Ciência, Tecnologia, Inovações e Comunicações, Campina \\ Grande, PB, Brazil \\ ${ }^{4}$ Departamento de Antibióticos, Universidade Federal de Pernambuco, Recife, PE, Brazil \\ ${ }^{5}$ Instituto de Pesquisas em Substâncias Bioativas, Universidade Federal do Vale de São Francisco, Juazeiro, BA, \\ Brazil \\ ${ }^{6}$ Instituto Agronômico de Pernambuco, Recife, PE, Brazil \\ Correspondence: Márcia Vanusa da Silva, Departamento de Bioquímica, Universidade Federal de Pernambuco, \\ Av. Prof. Moraes Rego, s/n, Cidade Universitária, CEP: 50670-420, Recife, PE, Brazil. Tel: 558-121-268-576. \\ E-mail: marcia.vanusa@ufpe.br
}

Received: July 8, 2018

doi:10.5539/jas.v11n3p282
Accepted: December 15, 2018 Online Published: February 15, 2019

URL: https://doi.org/10.5539/jas.v11n3p282

\begin{abstract}
This research aims to analyze the effect of the extract from a native plant from Caatinga, Allamanda blanchetti, in the induction of resistance mechanisms in a sugarcane variety smut-susceptible. Initially, it carried out a phytochemical analysis to know the main plant compounds used in this study. Diverse chemicals content in ethanolic extract from $A$. blanchetii were detected by thin-layer chromatography (TLC). Flavonoids, were more abundant compounds following by terpenes, stereroids and saponins. Under greenhouse conditions the sugarcane plants, SP-791011 (smut-susceptible), were sprayed with extracts from A. blanchetti extracted at cold at concentrations of $1000 \mathrm{ppm}$ and acilbenzolar-S-metil (ASM) (100 mg/L). Leaves were collected at 0, 24 and 48 hours after spraying and used in the RT-PCR analysis for to identify the defense gene expression. Change in gene expression were observed in the different treatments, especially in the expression of pathogenesis-related (PR) genes. The extract of $A$. blanchetti induced an increase in the glucanase expression and was more effective than ASM inducer. SNPRI gene show increased in the two treatment. The results indicate that $A$. blanchetti extracts was able to activate the resistance mechanism as observed in resistant plants. This paper is the first report about the use of Caatinga natural plant extracts inducing resistance genes against Sporisorium scitamineum in sugarcane susceptible genotype.
\end{abstract}

Keywords: Saccharum sp., induced resistance, smut disease, plant extract, PR-genes

\section{Introduction}

Sugarcane (Saccharum spp.) is a major crop in Brazil and in many countries. It is one of the most important crop for the sugar production and renewable biofuel energy worldwide. The sugarcane production has been affected by many biotic and abiotic stresses, among them fungal diseases are one of the most important. Sugarcane smut is one of the most serious diseases of sugarcane. The disease is caused by the fungus, Sporisorium scitamineum, which infects plants through buds on standing stalks or germinating buds in the soil (Sundar et al., 2012; Sánchez-Elordi et al., 2016), can cause considerable yield losses and reductions in cane quality (Olweny et al., 2008). The best control method is to use resistant cultivars, which are widely available in different countries where sugarcane is grown (Chen et al., 2012), however, costs make this strategy expensive. Induced resistance (IR) can be activated in plants by several substances, preventing or delaying pathogen entry or its subsequent activity in plant tissues, by their own defense mechanisms. Several inductor agents can induce the production of "signals" in plant tissue, triggering reactions that will result in a long-term protection against a wide range of 
plant pathogens. Perception occurs when inductor agents molecules bind to receptor molecules, probably located in the plasma membrane of the plant cell. These reactions trigger the activation of various defense mechanisms (Resende et al., 2007). These mechanisms may involve enzymes such as $\beta$-1,3-glucanase, peroxidase and chitinase, among others. Plant extracts with bioactive substances may presents the capacity to act as resistance inducers (Barros et al., 2015).

Phytochemical screening is very important in identifying new sources of therapeutically and industrially important compounds like alkaloids, flavonoids, phenolic compounds, saponins, steroids, tannins and terpenoids. Knowledge of the chemical constituents of plants is desirable because such information will be of value for the synthesis of complex chemical substances. Plant extracts that present bioactive substances may present the capacity to act as resistance inducer. Allamanda blanchetii is an ornamental plant of Allamanda genus in the Apocynaceae family. It is native plant of Caatinga, a semi-arid region of Brazil Northeastern, with a great diversity of plants and animals. Many active phytochemicals have been isolated from their leaves and roots (Sharmin et al., 2013; Mone t al. 2013; Savithramma et al., 2013). Several reports described the native plant extracts potential to control plant diseases (Barros et al., 2015; Dos Santos et al., 2015; Peixinho et al., 2017). Brazil's flora species present high potential as a source of bioactive substances for control of plant diseases. In light of the vast biodiversity of the Caatinga and the need to discover new bioactive compounds, it is fundamental importance to study the flora of this region, which has been insufficiently researched.

Therefore, the objective of this work was to study A. blanchetti potential extracts for the control of the fungus $S$. scitamineum, as inducer of mechanisms resistance in sugarcane and as natural fungicide, aiming to reduce the use of pesticides in this crop.

\section{Methods}

The experiment was conducted in a greenhouse at the Instituto Agronômico de Pernambuco (IPA) and Biochemistry Laboratory of the Universidade Federal de Pernambuco (UFPE), Recife, Brazil. The sugarcane cultivar SP-791011 (smut-susceptible), used in this experiment, was provided by Agro-Indústrias do Vale do São Francisco S.A.-AGROVALE.

A. blanchetii leaves were collected from fields localized in the Afrânio city (Pernambuco, Brazil), at the geographical position $8^{\circ} 47^{\prime} 88^{\prime \prime} \mathrm{S}$ and $40^{\circ} 93^{\prime} 79^{\prime \prime} \mathrm{W}$. The taxonomic identification was performed by Dr. Alexandre Gomes da Silva and a voucher specimen was deposited at the Herbarium IPA Dárdano de Andrade-Lima, Brazil (registration number 84112). Leaf tissues were dried in oven-dried at $40{ }^{\circ} \mathrm{C}$ for $72 \mathrm{~h}$ and then ground in a knife mill to obtain a fine and uniform powder. About $150 \mathrm{~g}$ of dried powdered leaves of the plant was subjected to maceration in cold $100 \%$ ethanol for $48 \mathrm{~h}$, with intermittent agitation. Then, the extract was filtered and the supernatant was concentrated in a rotary vacuum. This ethanolic extract was kept at $4{ }^{\circ} \mathrm{C}$ until the experiments for phytochemical analysis were done.

The phytochemical screening of the extract of $A$. blanchetti was performed by thin-layer chromatography (TLC), according to Harborne (1998), on silica plates (60F254, aluminum backed, $200 \mu \mathrm{m}$ layer thickness, $8.0 \times 5.0 \mathrm{~cm}$, Merck, Darmstadt, Germany). The presence of secondary metabolites were investigated using the adequate development systems. After development, the plates were air dried and sprayed with the revealers in a fume hood.

Sugarcane plants, variety SP-791011, were grown in PVC pots containing $15 \mathrm{~kg}$ soil. The experiment was carried out in a greenhouse $\left(29^{\circ} \mathrm{C}\right.$ and $\left.70 \% \mathrm{RH}\right)$ with 21 samples in randomized blocks and seven replications per treatment. At 105 days after germination was started applying the following treatments: (1) spraying with sterile distilled water (concentration 0); (2) spraying with crude extract of A. blanchetti, cold extraction, at concentration of $1000 \mathrm{ppm}$; (3) ASM (acilbenzolar-S-metil), at concentration of $100 \mathrm{mgl}^{-1}$. ASM is one of the elicitors more used in the control of plant diseases through induction of resistance and it was used in this experiment for the purpose of comparison with the results of gene expression of $A$. blanchetti. Leaf tissues were collected at $0 \mathrm{~h}, 24 \mathrm{~h}$ and 48 hours after induction. Samples were maintained at $-80{ }^{\circ} \mathrm{C}$ until processed. Total RNA was isolated from leaves using TRIzol ${ }^{\circledR}$ Reagent (Invitrogen) according to the manufacturer's instructions. The quality and concentration of total RNA were measured by electrophoresis on $1.2 \%$ agarose denaturing gel and spectrophotometer, respectively. Aliquot of $5 \mathrm{mg}$ of total RNA was used as a template for cDNA synthesis in RT-PCR analysis using the SuperScript ${ }^{\circledR}$ III kit (Invitrogen) following the manufacturer's recommendations. Complementary DNA (cDNA) obtained at $0 \mathrm{~h}, 24 \mathrm{~h}$ and $48 \mathrm{~h}$ of treatment was used to PCR amplification of PR genes. RT-PCR was performed under the following conditions: $50{ }^{\circ} \mathrm{C}$ for $30 \mathrm{~min}$ and $94{ }^{\circ} \mathrm{C}$ for $3 \mathrm{~min}$, followed by 30 amplification cycles $\left(94{ }^{\circ} \mathrm{C}\right.$ for $30 \mathrm{sec}, 55^{\circ} \mathrm{C}$ for $30 \mathrm{sec}$ and $72{ }^{\circ} \mathrm{C}$ for $\left.1 \mathrm{~min}\right)$ and $7 \mathrm{~min}$ at $72{ }^{\circ} \mathrm{C}$. The 
primers used to amplification of the PR genes are listed in Table 1. The final amplification product was separated on a $1.2 \%$ agarose gel, visualized and analysed by L-PIX EX software (Loccus).

Table 1. Primers sequence used to amplification of the PR genes and their respective annealing temperatures

\begin{tabular}{lll}
\hline Primer & Sequence 5'-3' & Annealing temperature $\left({ }^{\circ} \mathbf{C}\right)$ \\
\hline Quitinase S & AGAAGATGAAGCGGAAGACG & 59 \\
Quitinase A & CCCCTTGGTGTAGGTCCTTT & 60 \\
Glucanase S & CGAGTGAAAAGCAGGGACAG & 60 \\
Glucanase A & ATGTCGGAGTTGCCGTTCT & 59 \\
PR5 S & AAACAAGGCAGAGCACCAAC & 60 \\
PR5 A & GGGCAGAAGGTGACTTGGTA & 60 \\
Peroxidase S & AAAGGGTCCTAGCGTCCAAT & 59 \\
Peroxidase A & ACATTGACGAAGCAGTCGTG & 59 \\
$S N P R 1 f$ & TGTCTTCATCGTCGTCGTGCGT & 59 \\
$S N P R 1 r$ & TCCCAGGTCTCCAAAACCGTGAT & 61 \\
\hline
\end{tabular}

\section{Results}

Phytochemical investigation of crude organic extracts of $A$. blanchetti leaves revealed the presence of several secondary metabolites. Flavonoids were more abundant compounds following by terpenes, steroids and saponins (Table 2). This results showed that plant extract contain molecules with potential for the application against smut disease. Others metabolites such as alkaloids, coumarins, quinones and reducing sugars were absent in the extracts. To investigate whether the defence-related genes are induced by crude extract of $A$. blanchetti, total RNAs from sugarcane leaves were extracted and analyzed by RT-PCR. The gene expression analysis shown that the inducers were efficient in activating a metabolic pathway of defense (Table 3). Inducers ASM and $A$. blanchetti extract, used in this study, were both effective in inducing resistance genes, however, they showed differences in the expression of the Glucanase $48 \mathrm{~h}$ after induction. Expression of this gene was significantly greater in the treatment with $A$. blanchetti extracts as compared to ASM inducer. Peroxidase and Chitinase genes was 2-fold expressed at 48 hours after inoculation. Same result was observed in the treatment with the asm inducer. PR-5 gene was 2-fold expressed only at $24 \mathrm{~h}$ with $A$. blanchetti extracts. SCNPR1 gene, activator of the metabolic route of defense, had expression increased over time (3-fold) in both treatments, not varying in control.

Table 2. Phytochemical profile of the organic extracts of the $A$. blanchetti leaves

\begin{tabular}{llll}
\hline Secondary metabolites & Standards & Development system & Inference \\
\hline Flavonoids $^{1}$ & Quercetin, rutin & $\mathrm{A}$ & +++ \\
Phenylpropanoids & Chlorogenic acid & $\mathrm{A}$ & - \\
Triterpenes & $\beta$-sitosterol & $\mathrm{B}$ & ++ \\
Steroids & $\beta$-sitosterol & $\mathrm{B}$ & ++ \\
Saponins & - & $\mathrm{A}$ & ++ \\
Monoterpenes and sesquiterpenes & Tymol & $\mathrm{C}$ & ++ \\
Coumarins & Coumarin & $\mathrm{D}$ & - \\
Quinones & Lapachol & $\mathrm{D}$ & - \\
Alkaloids & Pilocarpine & $\mathrm{A}$ & - \\
Condensed proanthocyanidins and leucoanthocyanidins & Catechin & $\mathrm{A}$ & - \\
Hydrolyzable tannin & Gallic acid & $\mathrm{E}$ & + \\
Reducing sugars & Glucose & $\mathrm{F}$ & - \\
\hline
\end{tabular}

Note. A, AcOEt-HCOOH-AcOH- $\mathrm{H}_{2} \mathrm{O}(100: 11: 11: 27 \mathrm{v} / \mathrm{v}) ; \mathrm{B}$, Tolueno:AcOEt $(90: 10 \mathrm{v} / \mathrm{v}) ; \mathrm{C}$, Tolueno:AcOEt $(97: 3 \mathrm{v} / \mathrm{v}) ; \mathrm{D}, \mathrm{CHCl}_{3}-\mathrm{MeOH}(98: 2 \mathrm{v} / \mathrm{v}) ; \mathrm{E}, \mathrm{n}-\mathrm{BuOH}-\mathrm{H}_{2} \mathrm{O}-\mathrm{AcOH}(40: 50: 10 \mathrm{v} / \mathrm{v}) ; \mathrm{F}, \mathrm{n}-\mathrm{BuOH}-\mathrm{Me}_{2} \mathrm{CO}-\mathrm{TF}(\mathrm{pH}=$ $5,0)(40: 50: 10 \mathrm{v} / \mathrm{v})$. + trace; ++ present; - absent; +++ abundant; ${ }^{(1)} 3^{\prime}, 44^{\prime}-\mathrm{OH}$ flavonoids (aglycones, mono-, diand tri-glycosides). 
Table 3. Expression of proteins in sugarcane (smut-susceptible) genotype SP-791011 in response to induction with ASM (acilbenzolar-S-metil) and $A$. blanchetti extract at 0,24 , and 48 hours after induction

\begin{tabular}{|c|c|c|c|c|c|c|c|c|c|}
\hline \multirow{3}{*}{ PR-protein } & \multicolumn{9}{|c|}{ Treatment } \\
\hline & \multicolumn{3}{|c|}{ Control } & \multicolumn{3}{|c|}{ ASM elicitor } & \multicolumn{3}{|c|}{ A. blanchetti extract } \\
\hline & $0 \mathrm{~h}$ & $24 \mathrm{~h}$ & $48 \mathrm{~h}$ & $0 \mathrm{~h}$ & $24 \mathrm{~h}$ & $48 \mathrm{~h}$ & $0 \mathrm{~h}$ & $24 \mathrm{~h}$ & $48 \mathrm{~h}$ \\
\hline Glucanase & - & - & - & + & ++ & ++ & + & ++ & +++ \\
\hline Peroxidase & - & - & - & + & ++ & ++ & - & + & ++ \\
\hline Chitinase & - & - & - & + & ++ & ++ & + & ++ & ++ \\
\hline PR-5 & - & - & - & - & - & + & - & ++ & + \\
\hline ScNPR1 & - & - & - & + & ++ & +++ & + & ++ & +++ \\
\hline
\end{tabular}

\section{Discussion}

For investigate the sugarcane responses in the early stages, after application whith elicitors, we performed phytochemical studies and assessed the resistance gene expression profile of smut-susceptible sugarcane genotype. Medicinal plants contain secondary metabolites, which often play an important role in plant defenses, and are capable of destroying or inhibiting the growth of microorganism (Sumathi \& Anuradha, 2016). Antipathogenic properties of flavonoids result from their strong antioxidative properties. Their antifungal activity is based on the inhibition of spore development and mycelium hyphae elongation (Mierziak et al., 2014). The role of saponins in the plants serves an anti-feedant and to protect against phytopathogenic fungi (Koul, 2008). Essiett and Udo (2015), studied phytochemical screening of Allamanda cathartica. They found flavonoids was moderately present in the leaves, while saponins were present in traces in the leaves and flowers. Tannins were moderately present in the leaves, while terpenes were abundantly present in the stem, leaves and moderately present in the flowers. Like these cited reports, our analyzes revealed the moderate presence of tannins and saponins while flavonoids were more abundant. This indicates that the extracts of $A$. blanchetti were able to induce this compound which is correlated to the phytopathogenic defense mechanism.

Biological control is becoming increasingly important in integrated pest management programs, especially when discussing integrated production towards sustainable agriculture. Many plant and plant extracts have been reported to have antimicrobial properties against plant pathogenic fungi (Sharmin et al., 2013; Vergnes, 2014; Akladious et al., 2015; Santos et al., 2015). Allamanda species extract has been proved as effective in controlling plant pathogenic fungi (Islam, 2004; Ravikumar et al., 2013; Basar et al., 2011; Mone et al., 2013; Barros et al., 2015; Brito et al., 2018). However, there is a small report available in the studies on detailed analyzes of leaf extract and its antifungal activity against plant pathogens. Nevertheless, it is reported that A. blanchetii have different bioactivities, and then further investigation is important to isolate the active principles to correlate with their biological activities.

In the initiation of the defense in plants are activated two main routes in the induction of systemic resistance: SAR (Systemic Acquired Resistance) and ISR (Systemic Induced Resistance), which promote the expression of PR proteins and is mediated by a salicylic acid-dependent process. ASM (benzo-(1,2,3)-triadiazole-7-carbothioic acid Ester-S-methyl) is one of the most promising and most used inducers of resistance, which provides protection to a broad spectrum of pathogens. Providing increased resistance to diseases in many plant species, by their action similar to salicylic acid in the signal transduction pathway (Cruz et al., 2013). Studies shown that ASM induce the activity of 1,3- $\beta$-glucanase, peroxidase and chitinase, confirming the involvement of these enzymes in the systemic acquired resistance. Plant $\beta$-1,3-glucanases are pathogenesis-related (PR) proteins, which belong to the PR-2 family of pathogenesis-related proteins and are believed to play an important role in plant defense responses to pathogen infection (Ebrahim et al., 2011). The pathogenesis-Related gene 1 (PR1) is particularly induced during defense response, being used as a marker for establishment of SAR in plants. The NPR1 protein (non-expressor of pathogenesis related gene 1) is a transcriptional co-activator and positive regulator of SAR, a long-lasting mobile defense signal found in plants. The NPR1 gene has been cloned and characterized in Sugarcane (Saccharum spp. hybrids) (ScNPR1). It has been shown to share an $83 \%$ sequence identity with NPR1 from maize (ZmNPR1), as well as display a very close relationship with NPR1 from banana (MdNPR1) (Pirnia, 2016). Chen et al. (2012) noted that resistant sugarcane plants in contact with the pathogen activates this gene to prevent infection by S. scitamineum.

Lao et al. (2008) examined differential expression proteins in sugarcane smut-susceptible and resistant varieties after inoculation with $S$. scitamineum at 0,24 and 72 hours post inoculation. In the susceptible genotype PR-5 
protein and Peroxidase were up-regulated only at $24 \mathrm{~h}$ whereas they were up-regulated in resistant at both 24 and $72 \mathrm{~h}$ post inoculation. Glucanase and chitinase were up-regulated only resistant genotype at $24 \mathrm{~h}$ and $72 \mathrm{~h}$. In our study, with a susceptible genotype, glucanase and chitinase were expressed at different levels at 0,24 and $48 \mathrm{~h}$. This demonstrates that use of $A$. blanchetti extract as elicitor was able to induce defense genes in plants in response to sugarcane smut. Su et al. (2016) studied the response in sugarcane genotypes 0,24 and 48 hours after inoculation with $S$. scitamineum. Most proteins, differentially expressed, were closely related to sugarcane smut resistance such as pathogenesis-related protein 1 (PR1), PR5, beta-1,3-glucanase and peroxidase. Glucanase expression, in the resistant genotype, was 2 -fold (compared to control) at $24 \mathrm{~h}$, decreasing its expression at $48 \mathrm{~h}$. However expression level at 0 and $48 \mathrm{~h}$ were similar for both genotypes. Expression of PR1 was gradual over time and expressed for its intensity at $48 \mathrm{~h}$ in the susceptible genotype. Peroxidase was most expressed at $48 \mathrm{~h}$ (2-fold) in the resistant variety. Our results were similar to those cited above, however the expression of Glucanase was higher at $48 \mathrm{~h}$ after induction with $A$. blanchetti extracts. Glucanase and PR1 are the most highly induced (3-fold) as compared to control.

Extracts from Allamanda blanchetti and the ASM resistance inducer presented similar responses regarding induction of resistance gene expression. Thus, it is understood that the elicitation of both PR-proteins and secondary metabolism products, such as phenolic compounds and their derivatives, by the application of natural products may contribute to the reduction of sugarcane plant diseases.

\section{Remarks}

Natural products play an important role in the search for new active drugs. Medicinal plants from Caatinga's environments have been the subject of various studies in the search for new antimicrobial compounds. Based on the results obtained with the present study, the natural extract of $A$. blanchetti possess antimicrobial substances that can inhibit the growth of the pathogenic fungi. It was able to activate the resistance mechanism in a sugarcane smut-susceptible genotype, increasing PRs and ScNPR1 genes expression. In addition, it presented expression levels similar to ASM resistance inducer, demonstrates potential to be used as elicitor of resistance for alternative control of infection by fungus diseases in sugarcane.

\section{Acknowledgements}

This work was supported by Instituto Agronômico de Pernambuco (IPA), Fundação de Amparo à Pesquisa do Estado de Pernambuco (FACEPE), Conselho Nacional de Desenvolvimento Científico e Tecnológico (CNPq) and Universidade Federal de Pernambuco. The authors thank the Agro-Indústrias do Vale do São Francisco S.A.-AGROVALE.

\section{References}

Akladious, S. A., Isaac, G. S., \& Ahmed Abo-tahon, M. (2015). Induction and resistance against Fusarium wilt disease of tomato by using sweet basil (Ocimum basilicum L) extract. Canadian Journal of Plant Science, 95, 689-701. https://doi.org/10.4141/cjps-2014-127

Barros, J. S. G., Gomes, E. C. S., \& Cavalcanti, L. S. (2015). Effect of the Allamanda blanchetti extracts on the control of Alternaria brassicola in seedlings of kale. Revista Caatinga, 28(3), 36-46. https://doi.org/ $10.1590 / 1983-21252015 \mathrm{v} 28 \mathrm{n} 304 \mathrm{rc}$

Basar, M. K., Alam, M. J., Ferdous, R., Khokon, M. A. R., \& Meah, M. B. (2011). Allamanda tablet for controlling phomopsis blight and fruit rot of eggplant. International Journal of Agricultural Sustainability, 7, 23-29.

Bezerra Dos Santos, A. T., Araújo, T. F., Nascimento da Silva L. C., Silva, C. B., Oliveira, A. F., Araújo, J. M., ... Lima, V. L. (2015). Organic extracts from Indigofera suffruticosa leaves have antimicrobial and synergic actions with erythromycin against Staphylococcus aureus. Frontiers in Microbiology, 6(13), 1-7. https://doi.org/10.3389/fmicb.2015.00013

Brito, S. A., Almeida, C. L. F., Santana, T. I., \& Oliveira, A. R. S. (2018). Antiulcer Activity and Potential Mechanism of Action of the Leaves of Spondias mombin L. Oxidative Medicine and Cellular Longevity, 2-20. https://doi.org/10.1155/2018/1731459

Chen, J. W., Kuang, J. F., Peng, G., Wan, S. B., Liu, R., Yang, Z. D., \& Deng, H. H. (2012). Molecular cloning and expression analysis of a NPR1 gene from sugarcane. Pakistan Journal of Botany, 44(1), 193-200.

Cruz, M. F. A., Rodrigues, F. A., Polanco, L. R., Curvêlo, C. R. S., Nascimento, K. J. T., Moreira, M. A., \& Barros, E. G. (2013). Inducers of resistance and silicon on the activity of defense enzymes in the 
soybean-Phakopsora pachyrhizi interaction. Bragantia, 72(2), 162-172. https://doi.org/10.1590/S0006-870 52013005000025

Ebrahim, S., Usha, K., \& Singh, B. (2011). Pathogenesis related (PR) proteins in plant defense mechanism: Chitinase and $\beta-1,3$-glucanase in defensemechanism against malformation in mango (Mangifera indica L.). Scientia Horticulturae, 130, 847-852. https://doi.org/10.1016/j.scienta.2011.09.014

Essiett, A. U., \& Udo, E. S. (2015). Comparative phytochemical screening and nutritional potentials of the stems, leaves and flowers of Allamanda Cathartica (Apocynaceae). International Journal of Science and Technology, 4(6), 248-253.

Harborne, J. B. (1998). Phytochemical Methods (3rd ed.), Chapman \& Hall, Londres.

Islam, R. (2004). Chromatographic separation of components in garlic bulb and Allamanda leaf extracts inhibitory to Phomopsis vexans (Ph.D. Thesis. Mymensingh, Bangladesh Agricultural University).

Koul, O. (2008). Phytochemicals and Insect Control: An Antifeedant Approach. Critical Reviews in Plant Sciences, 27(1), 1-24. https://doi.org/10.1080/07352680802053908

Lao, M., Arencibia, A., Carmona, E., Acevedo, R., Rodríguez, E., León, O., \& Santana, I. (2008). Differential expression analysis by cDNA-AFLP of Saccharum spp. after inoculation with the host pathogen Sporisorium scitamineum. Plant Cell Reports, 27, 1103-1111. https://doi.org/10.1007/s00299-008-0524-y

Mierziak, J., Kostyn, K., \& Kulma, A. (2014). Flavonoids as Important Molecules of Plant Interactions with the Environment. Molecules, 19, 16240-16265. https://doi.org/10.3390/molecules191016240

Mone, M., Saieed, M. A. U., Dastogeer, K. M. G., Ali, M. A., \& Meah, M. B. (2013). Plumieride from Allamanda cathartica as an inhibitory compound to plant pathogenic fungi. Archives of Phytopathology and Plant Protection, 47, 1311-1326. https://doi.org/10.1080/03235408.2013.840103

Peixinho, G. S., Santos, C. M. G., Ribeiro, V. G., Amorim, E. P. R., Bispo, J. S., \& Carvalho, V. N. (2017). Avaliação da eficiência de extratos de plantas nativas da caatinga sobre o controle da podridão seca (Lasiodiplodia theobromae) em cachos da videira cv. Itália. Summa Phytopathologica, 43(2), 155-157. https://doi.org/10.1590/0100-5405/2166

Pirnia, S. (2016). Novel plant DNA binding protein: Non-expresser of Pathogenesis Related 1 gene (NPR1) involved in disease resistance (Ph.D. Thesis, Brock University St. Catharines, ON).

Ravikumar, M. C., \& Rajkumar, H. G. (2013). Antifungal activity of plants extracts against Alternaria solani, the causal agent of early blight of tomato. Archives of Phytopathology and Plant Protection, 46, 1897-1903. https://doi.org/10.1080/03235408.2013.780350

Resende, M. L. V., Costa, J. C. B., Cavalcanti, F. R., Ribeiro Júnior, P. M., \& Camilo, F. R. (2007). Selection of plant extracts to induce resistance and activate defense responses in cocoa against witches' broom disease. Fitopatolologia Brasileira, 32(3), 213-221. https://doi.org/10.1590/S0100-41582007000300005

Sánchez-Elordi, E., Baluska, F., Echevarríaa, C., Vicentea, C., \& Legaz, M. E. (2016). Defence sugarcane glycoproteins disorganize microtubules and prevent nuclear polarization and germination of Sporisorium scitamineum teliospores. Journal of Plant Physiology, 200, 111-123. https://doi.org/10.1016/j.jplph.20 16.05.022

Savithramma, N., Linga, R. M., \& Suhrulatha, D. (2013). Qualitative and quantification analysis of phytochemicals from leaf aqueous extract of Allamanda cathartica L. and Terminalia paniculata Roth. Journal of Pharma Research, 6(8), 821-825.

Sharmin, T., Sarker, P. K., Islam, F., Chowdhury, S. R., Quadery, T. M., Mian, Y., ... Ullah, S. (2013). Investigation of biological activities of Allamanda blanchetii, the violet Allamanda. Journal of Pharmacy Research, 6(7), 761-764. https://doi.org/10.1016/j.jopr.2013.07.010

Su, Y. C., Xu, L. P., Wang, Z. Q., Peng, Q., Yang, Y. T., Chen, Y., \& Que, Y. (2016). Comparative proteomics reveals that central metabolism changes are associated with resistance against Sporisorium scitamineum in sugarcane. BMC Genomics, 17, 1-21. https://doi.org/10.1186/s12864-016-3146-8

Sumathi, R., \& Anuradha, R. (2016). Phytochemical Screening and in Vitro Antioxidant Activity of Methanolic Extract of Flowers of Allamanda neriifolia Hook. International Journal of Pharmacognosy and Phytochemical Research, 8(7), 1111-1117. 
Sundar, A. R., Ashwin, N. M. R., Barnabas, E. L., Malathi, P., \&d Viswanathan, R. (2015). Disease resistance in sugarcane-an overview. Scientia Agraria Paranaensis, 4, 200-212. https://doi.org/10.18188/1983-1471/sap. v14n4p200-212

Vergnes, S., Ladouce, N., Fournier, S., Ferhout, H., Attia, F., \& Dumas, B. (2014). Foliar treatments with Gaultheria procumbens essential oil induce defense responses and resistance against a fungal pathogen in Arabidopsis. Frontiers in Plant Science, 5(477), 1-8. https://doi.org/10.3389/fpls.2014.00477

\section{Copyrights}

Copyright for this article is retained by the author(s), with first publication rights granted to the journal.

This is an open-access article distributed under the terms and conditions of the Creative Commons Attribution license (http://creativecommons.org/licenses/by/4.0/). 